\title{
GERAKAN ANTI KORUPSI MALANG CORRUPTION WATCH
}

\author{
Yusuf Adam Hilman ${ }^{1}$, Herlambang Septa Nugraha ${ }^{2}$ \\ Program Studi Ilmu Pemerintahan, FISIP, Universitas Muhammadiyah Ponorogo \\ adamhilman@umpo.ac.id
}

\begin{abstract}
ABSTRAK
Perjalanan bangsa Indonesia tidak terlepas dari bencana yang namanya korupsi, berbagai persoalan korupsi kemudian membuat bangsa ini terpuruk dan mencoba bangkit, berupaya dengan sangat keras untuk melakukan pemberantasan korupsi, kemudian lahirlah KPK, komisi ini kemudian tumbuh dan menjelma sebagai kekuatan terlembaga, namun begitu KPK lahir dalam perjalannya banyak yang menghalangi dan ingin menghilangkan peranannya, sehingga gerakannya sering kali di politisi, selain itu muncul persoalan terkait luas wilayah yang menyebabkan keterbatasan KPK dalam menjalankan tugas dan fungsinya. Disinilah kemudian diperlukan lembaga di daerah yang memiliki gerakan berbasis di lingkungan masyarakat untuk menjadi oposisi dari pemerintah dalam upaya pemberantasan korupsi, salah satunya adalah Malang Corruptions Watch yang ada di Malang raya, sehingga menarik untuk meneliti sejauhmana sepak terjang MCW sebagai sebuah gerakan sosial, penelitian ini menggunakan model kualitatif deskriptif, dengan sumberdata berupa hasil wawancara dan dokumentasi. MCW merupakan organisasi non pemerintah yang tumbuh dan berkembang sebagai sebuah gerakan sosial yang muncul atau hadir dari mantan aktivis di era reformasi, MCW menggunakan 3 strategi dalam pemberantasan korupsi yakni, pencegahan, penegakan hukum, pendidikan anti korupsi.
\end{abstract}

Kata Kunci: gerakan sosial, anti korupsi, Malang coruption watch

\begin{abstract}
Journey of the Indonesia nation, cannot be separated from the whose name corruption, various corruption problems then make a nation it down and trying to emerge,tries to with very hard to do the eradication of corruption, then now KPK, the commission would grow up and incarnate as a institutional power power terlembaga, however KPK but many that blocks, so that his movement often in politician, in addition problems arise related the area of that causes limited KPK in running tasks and functions. Then institutions here needed in regions have motion based in society to be opposition from government in the fight against corruption the, one of which is Malang Corruptions Watch that is Great Malang, to attract to scrutinize about lunge MCW as of a motion social, this research use the model descriptive qualitative, with data source of interviews and documentation. MCWis non-governmental organizations which has grown and developed social as of a motion that which appears or present of former activist in the era of reformasi, MCW use 3 strategies in efforts to eradicate corruption namely, prevention, law enforcement, anti-corruption education.
\end{abstract}

Keyword: social action, anti-corruption, Malang coruption watch

\footnotetext{
2. Program Studi Ilmu Pemerintahan, FISIP, Universitas Muhammadiyah Ponorogo herlambang130995@yahoo.com
} 


\section{PENDAHULUAN}

Di Indonesia, kita menyebut korupsi dalam satu tarikan nafas sebagai "KKN" (korupsi, kolusi, nepotisme). "Korupsi" selama ini mengacu kepada berbagai "tindakan gelap dan tidak sah" (illicit or illegal activities) untuk mendapatkan keuntungan pribadi atau kelompok (Azyumardi, 2002).

KKN selain sebagai sebuah tindakan gelap atau illegal, dalam istilah hukum sering disebut juga sebagai kejahatan khusus, sehingga perlu penanganan yang khusus pula. Penegakan hukum terhadap tindak pidana korupsi sangat berbeda dengan tindak pidana yang lain, diantaranya karena banyaknya lembaga yang berwenang untuk melakukan proses peradilan terhadap tindak pidana korupsi sebagaimana telah di sebutkan dalam alenia pertama. Kondisi demikian merupakan konsekuensi logis dari predikat yang di letakkan pada tindak pidana tersebut sebagai extra ordinary crime (kejahatan luar biasa), model kejahatan ini memiliki daya hancur yang luar biasa karena dapat merusak sistem dan lini kehidupan sebuah bangsa (Andrisman, 2008).

Korupsi merupakan kejahaan yang memiliki dampak luar biasa, menurut Indonesia International Transparency (TII), Indonesia adalah Negara yang berada di wilayah ASEAN dengan peringkat 118 atau 4 (empat) negara terbawah dengan dampak korupsi yang sangat buruk (Pratomo dan Kriyantono, 2013).

Tindak pidana khusus atau extra ordinary crime merupakan salah satu kejahatan yang memiliki dampak cukup signifikan di Indonesia, dari beberapa catatan yang coba penulis himpun, pasca bergulirnya otonomi daerah, ada trend kenaikan kasus korupsi yang menjerat kepala daerah, dengan beberapa model, seperti: suap, gratifikasi, mark up anggaran, dan lain sebagainya. Dari data yang kami kumpulkan, Komisi Pemberantasan Korupsi, menyatakan pihaknya menjerat sedikitnya 63 kepala daerah sepanjang 2004-2016 dengan modus terbesar adalah suap. Kepala daerah yang dimaksud terdiri dari 52 bupati/walikota dan 11 gubernur yang terjerat berbagai kasus korupsi. ${ }^{1}$

Komitmen pemerintah Indonesia untuk membasmi korupsi sudah mulai tampak hasilnya. Kendati begitu korupsi yang sudah berurat berakar dalam kehidupan sehari hari masyarakat Indonesia dirasa masih terjadi di banyak daerah. Korupsi malah dominan dilakukan oleh kalangan pejabat di mana didapati ada banyak mantan bupati, mantan gubernur, mantan

\footnotetext{
${ }^{1}$ CNN Indonesia, 2016. KPK Jerat 63 Kepala Daerah dalam 1 Dekade, diakses pada pada 15 Mei 2018 dari https://www.cnnindonesia.com/nasional/20160928131449-12-161770/kpkjerat-63-kepala-daerah-dalam-1-dekade.
} 
Yusuf Adam Hilman, Herlambang Septa Nugraha

anggota DPRD dan mantan pejabat birokrasi di daerah yang tersangkut pidana korupsi di mana tindakan korupsi mereka lakukan saat memegang jabatan tertentu di daerah (Hadi, 2010).

Perkembangan pemberantasan korupsi semakin meningkat dengan meningkatnya penangan perkara korupsi dari segi kuantitas dan kualitas, yang tidak hanya fokus pada perkara dalam skala kecil, tetapi juga dalam skala besar dan berdampak luas. Namun, masih ditemui kendala dalam hal rendahnya komitmen dan belum meratanya pemahaman di tingkat pusat dan daerah. upaya pencegahan dan pemberantasan korupsi ini masih menjadi permasalahan pokok dalam pencegahan dan pemberantasan korupsi (Situmorang, 2014).

Komitmen dan juga pemahaman yang merata menjadikan KPK agak kesusahan dalam melakukan tugas dan fungsinya, mengingat luas wilayah yang tersebar dari Sabang sampai Merauke, membuat KPK harus bekerja keras. Upaya yang paling masuk akal dan bisa dilakukan adalah dengan menggandeng lembaga yang ada di daerah, mengingat luas wilayah Indonesia terdiri dari 34 Provinsi dengan ratusan Kabupaten dan kota, maka tidak akan efektif upaya tersebut, oleh karena itu dibutuhkan peran serta masyarakat dan lembaga swadaya yang bisa membantu dan mempermudah tugas KPK, untuk bersinergi dengan baik (Kompas, 2018).

Kerjasama dan kemitraan yang dibentuk oleh KPK merupakan salah satu inisiatif yang perlu di apresiasi sebagai bentuk pelaksanaan tugas serta kewenangan KPK, sehingga dapat memperkuat kelembagaan KPK sebagai salah satu badan anti rusuah. Pelaksanaan kegiatan anti korupsi di lain sisi, menurut saya tidak hanya menjadi kewajiban KPK, melainkan bisa juga dilakukan lembaga swadaya masyarakat non pemerintah ataupun non government organization, seperti pembahasan diatas, karena keterbatasan sumber daya manusia serta luas wilayah Negara Kesatuan Republik Indonesia, menjadi sebuah penghalang atau penghambat KPK untuk menjangkau semua wilayah tersebut.

Gerakan anti korupsi melalui LSM di daerah bergerak mengikuti kebutuhan dan juga kondisi akuntabilitas yang ada di daerah, salah satunya yang ada di wilayah Malang Raya, meliputi: Kota Malang, Kabupaten Malang, dan Kota Batu, beberapa waktu yang lalu sempat di hebohkan dengan adanya operasi tangkap tangan (OTT) yang dilakukan KPK terhadap mantan Walikota Batu, dan selang beberapa minggu kemudian, terdengar kembali berita terkait kasus suap yang menimpa mantan Walikota Malang bersama anggota Dewan Perwakilan Daerah, tentu hal tersebut sontak menghebohkan, namun yang menarik dibalik kejadian tersebut,yakni bagaimana peranan badan, atau lembaga sosial kemasyarakatan yang ada di 
Malang Raya khususnya dalam kegiatan anti rasuah, salah satunya adalah Malang Corruption Watch atau yang biasa di sebut MCW.

MCW adalah sebuah Lembaga Swadaya Masyarakat Anti Korupsi yang berawal dari komunitas diskusi yang terdiri dari kumpulan kecil aktivis yang sudah berjalan sebelum reformasi 1998. MCW resmi berubah menjadi LSM pada 31 Mei 2000 dan terinspirasi oleh adanya Indonesia Corruption Watch (ICW). MCW menjadi rujukan publik dan media massa di Malang Raya terkait kasus korupsi yang terjadi di wilayah Malang Raya yang meliputi Kabupaten Malang, Kota Malang, dan Kota Batu.(Larasati 2018)

MCW sebagai representasi CSO berperan besar dalam membantu upayapemberantasan korupsi di wilayah Malang Raya. MCW menjadi elemen kritis pemerintahan Indonesia yang berusaha memperjuangkan dan menjunjung tinggi nilai akuntabilitas dalam pemerintahan demokratis. Oleh karenanya, munculnya CSO seperti MCW di kota-kota lainnya yang terus menjaga profesionalitasnnya diharapkan menjadi kontribusi besar dalam tata kelola pemerintahan yang baik(Larasati, 2018).

MCW dan FMPP menginisiasi kesadaran masyarakat secara kolektif dengan membuat kegiatan - kegiatan seperti, seminar, workshop, Focus Group Discussion (FGD), pelatihan maupun penerbitan buku, kegiatan yang dilakukan diharapkan mampu meningkatkan kesadaran berpolitik masyarakat supaya bisa menjadi agen perubahan yang peka terhadap kondisi di daerahnya, kegiatan tersebut juga mengajak Pemerintahan di Malang Raya supaya dapat bersinergi dalam upaya menciptakan penyelenggaraan Pemerintah yang baik dan bersih (Salahudin, 2016).

Sekolah Antikorupsi (Sakti) yang didirikan Malang Corruption Watch (MCW) pada 2008. Dalam suasana nonformal dan penuh kesederhanaan, sekolah antikorupsi ini menjadi wadah strategis untuk mencetak para kader antikorupsi. Melalui sekolah antikorupsi, MCW menyampaikan edukasi secara terstruktur, tidak sekadar sosialisasi dan kampanye "Pendidikan antikorupsi semacam itu penting, untuk mencetak kader antikorupsi yang siap melakukan advokasi dan pengorganisasian masyarakat," kata Divisi Sekretariat Badan Pekerja MCW Bayu Diktiarsa Pratama. $^{2}$

Sepak terjang MCW, memberikan gambaran kepada kita khususnya prihal eksistensi dan konsistensinya dalam melakukan aktivitas rutin dalam menyuarakan gerakan anti korupsi,

${ }^{2}$ Inisiatif Masyarakat untuk Pendidikan Antikorupsi diakses dari http://kpk.go.id/id/berita/berita-kpk-kegiatan/3981-inisiatif-masyarakat-untuk-pendidikanantikorupsi pada 16 mei 2018 
Yusuf Adam Hilman, Herlambang Septa Nugraha

berbagai kegiatan dan juga program yang dijalankan, membentuk pola-pola yang dapat dikembangkan dan di sebarluaskan ke seluruh penjuru negeri, seperti apakah model lembaga anti korupsi yang digagas oleh organisasi MCW, hal ini kemudian menarik untuk di teliti.

\section{METODE PENELITIAN}

Penelitian ini menggunakan jenis penelitian kualitatif deskriptif dengan menekankan pada penggambaran fenomena yang terjadi di lapangan secara deskriptif. Penelitian kualitatif merupakan penelitian yang bermaksud memahami fenomena tentang apa yang dialami oleh subjek penelitian, misalnya perilaku, persepsi, motivasi, tindakan, dan lain-lain secara holistik, dan dengan cara deskripsi dalam bentuk kata-kata dan bahasa, pada suatu konteks khusus yang ilmiah dan dengan memanfaatkan berbagai metode ilmiah (Damayanti. Gustomy. dan Haboddin, 2017)

Penulis dalam mengumpulkan data, memanfaatkan sumber data primer, seperti: hasil wawancara, dan juga dokumentasi, data-data kemudian dianalisis tersebut digunakan untuk menunjang uraian deskriptif, melalui beberapa tahapan, yakni: Pertama, tahapan dalam pengumpulan data tertulis yang relevan dengan data yang diperlukan untuk kelengkapan penelitian. Dalam pengumpulan data ini peneliti menggunakan teknik pengumpulan data dengan studi kepustakaan, yaitu mengumpulkan data dari literatur dengan cara menelaah isinya melalui buku-buku, catatan, manuskrip dan dokumen-dokumen yang ada serta melakukan wawancara. Kedua, menguji dan menganalisa data secara kritis, dengan kritik ini diharapkan dapat mendapatkan validitas sumber data (baik sumber primer, sumber sekunder, sumber sejarah dan sumber teoritik) yang digunakan dalam penelitian. Ketiga, menghubungkan peristiwa yang satu dengan peristiwa lain sehingga menjadi satu rangkaian fenomena (Argenti, 2017).

Penentuan responden menggunakan purposive sampling dan snowball sampling. Instrumenu tama dalam pengambilan data adalah interview dengan berpegang pada Interview Guide yang favorable (positif) (Setyawan. Dody, 2014). Pemilihan informan berdasarkan pada karakteristik tertentu yang dianggap mempunyai keterkaitan dan mengetahui permasalahan yang akan di teliti mendalam. Hal ini dilakukan dengan cara wawancara kepada kepala sekertariat dan dokumentasi Malang Corruption Watch yaitu Buyung Jaya Sutrisna informan akan memberikan informasi tentang sepak terjang Malang corruption watch dalam pemberantasaan korupsi di Malang Raya. 
Pengumpulan data primer dilakukan dengan cara observasi non-partisipasi dan partisipasi, serta wawancara bebas dan wawancara terbimbing (Nugroho, 2014). Pengumpulan data dilakukan dengan metode wawancara, observasi, dan telaah dokumen yang berkaitan dengan penelitian ini. Setelah data terkumpul, dilakukan uji keabsahan data dengan cara triangulasi sumber dan triangulasi teknik, juga dilakukan member check. Tehnik analisis data dilakukan dengan cara penyajian data, reduksi data, dan penarikan kesimpulan (Acetylena, 2013).

Menggunakan analisis data spiral, peneliti terlibat dalam suatu proses dinamis yang bergerak dari satu lingkaran ke lingkaran berikutnya dan bukan proses linear yang sudah baku. Proses dimaksud meliputi: (a) pengelolaan data yang menghasilkan unit atau fail; (b) membaca dan membuat catatan yang menghasilkan catatan-catatan berdasarkan lintas pertanyaan dan refleksi; (c) mendiskripsikan, mengklasifikasi, menginterpretasi yang menghasilkan konteks, kategori, dan komparasi; dan (d) menyajikan, memvisualisasikan yang menghasilkan matriks (Nugroho, 2014).

\section{KERANGKA TEORI/KONSEP}

\section{Korupsi}

Korupsi dalam sejarah peradaban manusia merupakan salah satu masalah yang senantiasa menyertai perjalanan kehidupan manusia. Perilaku yang dapat digolongkan ke dalam tindakan korupsi seperti penyuapan dapat ditemukan dalam peradaban kuno masyarakat Yahudi, Cina, Jepang, Yunani, dan Romawi. Bahkan korupsi dengan skala besar yang mempengaruhi kehidupan masyarakat telah terjadi pada masa peradaban India kuno. Pada peradaban Indonesia sendiri, korupsi juga telah berlangsung lama. Hal ini misalnya dapat dilihat dalam tulisan Smith, Menurut Smith, korupsi di Indonesia dapat ditemukan sejak mulai masuknya Vereenigde Oost-Indische Compagnie (VOC) ke Indonesia pada abad ke-18 dan bahkan jauh sebelum itu apabila dilihat dari perilaku tradisional yang dipraktikkan dalam penyelenggaraan kehidupan bernegara di era sejumlah kerajaan nusantara. Karenanya dapat dikatakan bahwa korupsi merupakan endemik yang dapat ditemukan pada semua negara di dunia dengan berbagai tingkatan aplikasinya (Kurniawan, 2009).

Istilah korupsi berasal dari Bahasa Latin corruptus yang berarti busuk, rusak, menggoyahkan, memutar balik, dan menyogok mencakup unsur-unsur seperti melanggar hukum yang berlaku, menyalahgunakan wewenang, merugikan negara, dan memperkaya diri sendiri. Pengertian ini selaras dengan definisi yang digunakan Syed Husein Al-Attas, bahwa substansi korupsi adalah penyalahgunaan kepercayaan untuk kepentingan pribadi. Dengan demikian, segala bentuk penyalahgunaan wewenang untuk memperkaya diri, tercakup dalam apa yang disebut dengan 
Yusuf Adam Hilman, Herlambang Septa Nugraha

tindakan korupsi. Dalam konteks ini pula, bahwa poin penting dalam praktik korupsi adalah penyalahgunaan wewenang, kekuasan dan kepercayaan. Segala bentuk penyalahgunaan ini akan dengan mudah diidentifikasi sebagai praktik korupsi (Fawaid, 2010).

Menurut Soejono Karmi ada beberapa akibat dari tindakan korupsi diantaranya: 1) Merusak sistem tatanan masyarakat, norma - norma masyarakat dirusak oleh persekongkolan yang di dukung publik, 2) Penderitaan sebagian besar masyarakat, baik dalam sektor ekonomi, administrasi, politik maupun hukum, 3) Kehancuran perekonomian suatu Negara yang diakibatkan tindak korupsi secara langsung ataupun tidak langsung akan mengakibatkan penderitaan bagi sebagian besar masyarakat (Sina, 2008).

Korupsi bagaikan sebuah virus yang menjangkit secara perlahan-lahan, jika dibiarkan akan segera menjalar keseluruh bagian tubuh, maka di perlukan upaya yang berkesinambungan supaya bisa mengatasi semua persoalan yang muncu. Upaya kooperatif dan preventif yang dilakukan oleh lembaga Negara juga tidak banyak membawa perubahan, sehingga kita tidak dapat mengandalkan peran pemerintah, mengingat luas wilayah yang dimiliki Indonesia, membuat upaya penanggulangan korupsi menjadi sangat berat, selain itu keterbatasan sumber daya manusia yang dimiliki oleh lembaga Negara, menyebabkan kegiatan tersebut menjadi tidak optimal.

\section{Gerakan Sosial}

Gerakan sosial lahir dari aksi terhadap sesuatu yang tidak diinginkan rakyat atau menginginkan perubahan kebijakan. Gerakan sosial menurut Herbert Blumer, yaitu: ketidakpuasan sosial (social ferment), antusiasme orang banyak (popular excitement), formalisasi (formalization), dan pelembagaan (institutionalization).Sedangkan menurut Christiansen, menjelaskan keempat tahap gerakan adalah tahap kemunculan (emerge), tahap koalisi (coalescene), tahap formalisasi (bureaucratization), dan tahap surut (decline) (Yuanjaya, 2015).

Gerakan sosial pada hakikatnya merupakan hasil perilaku kolektif, yaitu sebuah perilaku yang dilakukan bersama-sama oleh sejumlah orang tidak bersifat rutin dan perilaku mereka merupakan hasil tanggapan atau respons terhadap ransangan tertentu. Akan tetapi, gerakan sosial berbeda dengan perilaku kolektif. Gerakan sosial sifatnya lebih terorganisasi dan lebih memiliki tujuan dan kepentingan bersama dibandingkan perilaku kolektif. Perilaku kolektif dapat terjadi secara spontan, namun gerakan sosial memerlukan sebuah penggorganisasian massa (Nurlindah. Kaharudin, 2016). 
Doug McAdam dkk. mengemukakan tiga kerangka strategis dalam membentuk sebuah gerakan sosial, yakni memanfaatkan peluang politik (political opportunities), memobilisasi struktur (mobilizing structures), dan melakukan penyusunan proses gerakan (framing process) (Muhsin, 2012).

\section{PEMBAHASAN}

\section{Profile Malang Coruption Watch}

\section{Kelahiran Malang Coruption Watch}

Berawal dari komunitas diskusi para aktivis, ada aktivis mahasiswa, mantan aktivis mahasiswa dan beberapa dosen yang mempunyai concern pada pemantauan kebijakan publik di Malang Raya (Kota Malang, Kota Batu, dan Kabupaten Malang). Komunitas diskusi ini sudah berjalan sejak sebelum reformasi 1998 berlangsung. Kemudian pada akhir tahun 1999, komunitas diskusi ini lebih fokus pada agenda-agenda pemantauan dan pemberantasan korupsi. Munculnya agenda ini diinspirasi oleh keberadaan Indonesian Corruption Watch (ICW). Yang kemudian secara formal Malang Corruption Watch dideklarasikan pada tanggal 31 Mei 2000, setelah mengalami proses diskusi internal maupun eksternal hampir selama 7 bulan sejak November 1999. Malang Corruption W atch lahir didasari oleh suatu kenyataan terjadinya praktikpraktik KKN di Malang Raya, seiring dengan pelaksanaan otonomi daerah. Praktik KKN hampir terjadi di semua sektor penyelenggara negara di daerah seperti pemerintah daerah, parlemen (DPRD) maupun lembaga judisial, yang dibarengi dengan tidak adanya kemauan politik (political will) untuk memberantas KKN secara menyeluruh, yang pada akhirnya proses pembangunan ekonomi dan sosial politik tidak dapat dinikmati oleh rakyat secara adil. Kondisi inilah yang kemudian mengakibatkan tersumbatnya proses mewujudkan demokratisasi dan keadilan sosial bagi kehidupan rakyat (Wawancara dengan Kepala Sekretariat dan Dokumentasi).

Sebagai salah satu lembaga yang konsen dalam agenda pemberantasan korupsi, penguatan gerakan sosial anti korupsi merupakan asa yang harus dicapai. Agenda pemberantasan korupsi yang efektif, efisien dan independen merupakan harapan besar untuk mengeluarkan republik ini dari penyakit akut korupsi. Sehingga dukungan publik menjadi kunci untuk mendorong agenda pemberantasan korupsi yang kuat, agenda pemberantasan korupsi yang dapat mempercepat Indonesia keluar dari mata rantai kemiskinan dan kesejahteraan yang tertunda. Oleh karena itu, agenda pemberantasan korupsi terus dioptimalkan dan menguatkan lembaga antikorupsi yang telah ada di Indonesia. Untuk mencapai visi dan misi Malang Corruption $W$ atch dukungan publik menjadi basis untuk menggalang kekuatan bersama dalam memerangi akut 
kosupsi di negeri ini. Sangat mustahil korupsi dapat dilumpuhkan apabila tatanan birokrasi, politik, ekonomi, pendidikan, dan hukum belum steril dan bebas dari korupsi, kolusi dan nepotisme. Seperti yang kita ketahui bahaya dari korupsi dapat merusak sendi-sendi moral kehidupan berbangsa dan bernegara. Oleh karena itu, gerakan sosial anti korupsi harus terus dikumandangkan untuk menciptakan iklim politik yang beretika, birokrasi bersih, ekonomi kerakyatan, pendidikan berkualitas dan hukum yang adil serta membangun generasi anti korupsi. Dalam mewujudkan hal tersebut, gendang perlawanan terus ditabuh untuk menyatakan perang melawan korupsi (Wawancara dengan Kepala Sekretariat dan Dokumentasi).

\section{Struktur Organisasi Malang Coruption Watch}

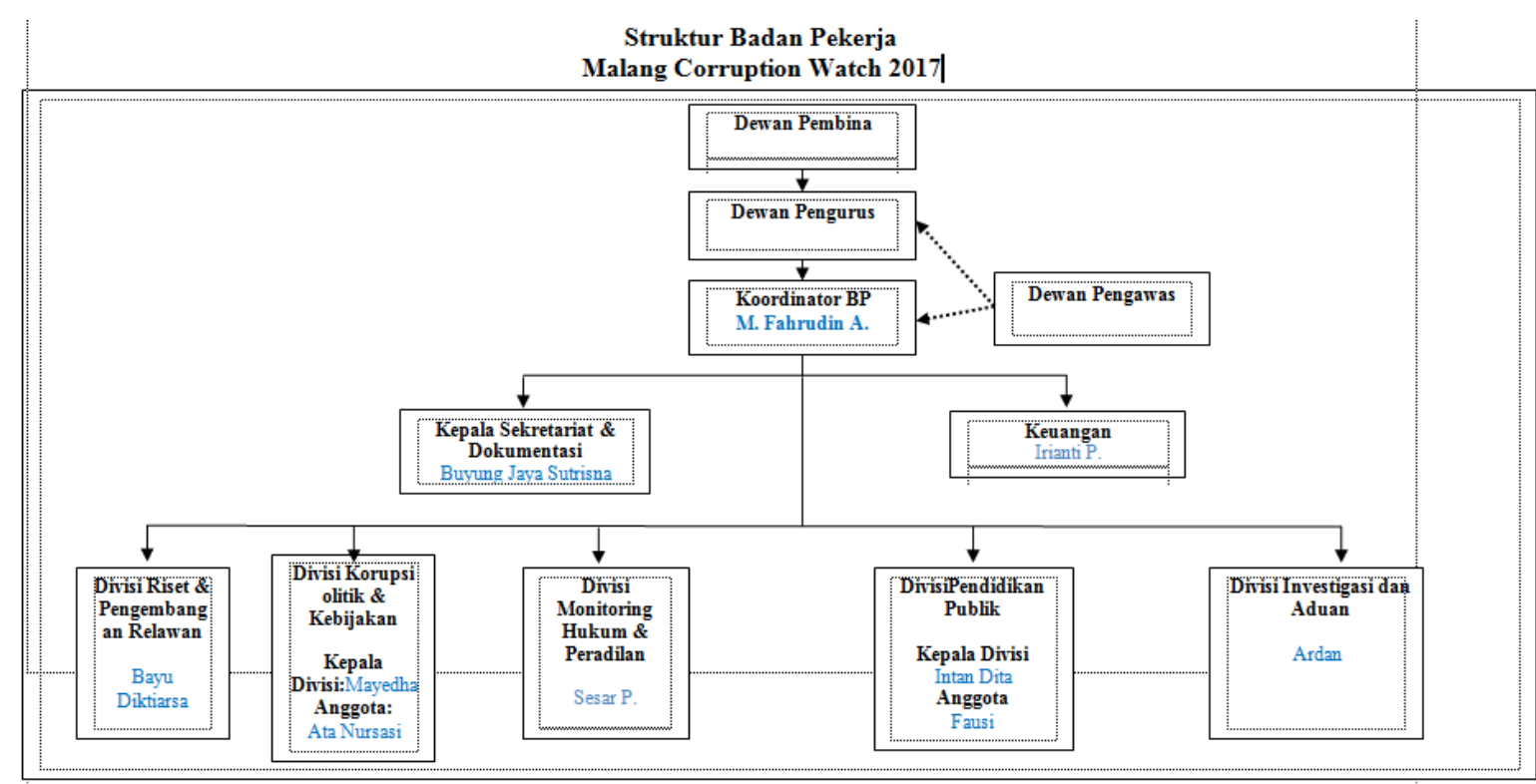

Sumber : Dokumen MCW

Struktur organisasi tersebut kemudian disebut sebagai badan pekerja, yang memiliki tugas dan fungsi, sehingga secara tersetruktur melaksanakan kegiatan dan tanggung jawabnya masing masing.

\section{Pendanaan Organisasi Malang Coruption Watch}

Sumber dana Malang Corruption Watch di kelola sendiri dari melalui usaha-usaha sendiri melalui penjualan kaos, topi, buku dan bahkan para anggota Malang Corruption Watch membuat semacam warung untuk mendapatkan uang guna itu semua di masukan ke pedanan kegiatan Malang Corruption Watch untuk biaya oprasional, biaya gerakan, biaya transpot. dan ada juga sumber pedanan dari NGO yang lain seperti ICW, dari LBH Surabaya, dan lain-lain yang satu visi dan semua dana tersebut di gunakan untuk: 1) Di gunakan untuk aksi, 2) Di buat untuk 
forum warga, 3) Biaya konsumsi kegiatan, 4) Di buat alat- alat kampanye anti korupsi berupa: poster, brosur, animasi gambar KPK tangkap koruptor. Para kader Malang Corruption Watch sangat independen jadi mereka melakukan sendiri untuk pencarian dana tanpa campur tangan dari pemerintah karena untuk menjaga sebuah netralitas lembaga (Wawancara dengan Kepala Sekretariat dan Dokumentasi).

\section{Program Kerja Malang Corruption Watch}

\section{Kegiatan Malang Corruption Watch}

Melakukan kajian rutin anti korupsi internal Malang Corruption Watch dan monitoring soal setiap kebijakan pemerintah Kabupaten Malang, Kota Malang dan Kota Batu, memberikan pendidikan anti korupsi ke warga melalui forum warga yang tersebar di Malang Raya (Kabupaten Malang, Kota Malang, dan Kota Batu) dan kajian rutin di lakukan setiap minggu atau bulan tujuan dari hal ini adalah agar masyarakat menyadari betul atas hak" mereka sebagai rakyat dan bisa mengadvokasi dirinya sendiri. Dan melakukan sebuah aksi masa guna menolak praktek korupsi di Malang Raya seperti yang dilakukan di Alun-Alun Kota Batu. Hal tersebut agar menumbuhkan rasa dan tanggung jawab kepada masyarakat Malang Raya agar sadar hakhak mereka tidak selalu terdzolimi oleh penguasa di Malang Raya (Wawancara dengan Kepala Sekretariat dan Dokumentasi).

Kegiatan Malang Corruption Watch hampir setiap hari para anggota Malang Corruption Watch berkumpul di kantor mereka yang beralamat di Jl Joyosuko Metro, Kec Lowokwaru, Kota Malang. Mereka berkumpul untuk berdiskusi untuk tentang kasus-kasus terbaru di wilayah Malang Raya dan para anggota Malang Corruption Watch sering mengadakan kegiatan-kegiatan semcam seminar anti korupsi yang di tujukan kepada masyarakat, dan para anggota Malang Corruption Watch juga melakukan kontrol setiap kebijakaan dari pemerintah agar setiap kebijakan semua harus pro rakyat kecil agar berjalannya pemerintahaan di Kabupaten Malang, kota Malang, dan kota batu berjalan secara baik jauh dari kata-kata KKN, dan melakukan aksi damai jika lembaga terkait tidak mampu menyelesaikan KKN di Malang Raya tujuan dari aksi tersebut agar lembag-lembaga yang berhak menganin kasus korupsi untuk segera turun tangan mengankap para tersangka korupsi di Malang Raya. Kegiatan lain dari anggota Malang Corruption Watch guna mengumpulkan dana untuk kegiatan mereka ada beberapa cara yang mereka lakukan dengan membuat topi, sablon, dan mereka memiliki sebuah cafe kopi. Malang Corruption Watch melakukan kegiatan tersebut untuk melakukan diskusi untuk membahas isu terkini guna menciptakan sebuah gerakan anti korupsi di Malang Raya dan jika ada sebuah kasus mereka akan melaporkannya kepada pihak yang berwajib (Wawancara dengan Kepala Sekretariat dan Dokumentasi). 
Yusuf Adam Hilman, Herlambang Septa Nugraha

\section{Tugas Malang Corruption Watch}

Ada beberapa tugas MCW, diantaranya: 1) Melakukan pengontroalan APBD daerah (Kabupaten Malang, Kota Batu, dan Kota Malang) selalu melakukan pengontrolan setiap 1 bulan sekali kalau terbukti terjadi penyelewengan akan di laporan di pihak berwajib untuk menangani kasus tersebut. 2) Melakukan monitoring setiap ada proyek dari pemerintah daerah. Mengontrol setiap proyek pemerintah dengan cara penyidikan langsung di lapangan untuk memastikan proyek sesuai dengan anggaran atau tidak. 3) Melakukan advokasi jika ada rakyat yang terzolimi oleh pemerintah, Misal ada sebuah kasus yang melibatkan rakyat kecil maka Malang Corruption Watch akan bersedia menjadi advokasi terhadap rakyat yang terzolimi. 4) Memberikan pendidikan anti korupsi kepada masyarakat. 5) Memberikan informasi kepada pihak penyidik jika terjadi kasus korupsi, tugas-tugas Malang Corruption Watch melakukan kontrol setiap kebijakan pemerintah daerah agar tidak terjadi praktek KKN dalam setiap kebijakaan Pemda (Wawancara dengan Kepala Sekretariat dan Dokumentasi).

\section{Strategi Malang Corruption Watch}

Dengan cara melakukan kajian di forum-forum warga dan memberikan informasi mengenai hak-hak warga setiap satu bulan sekali bahkan kadang dalam sebulan sampai 3-4 kali, dengan cara melakukan kampanye anti korupsi ke warga melalui brosur, pamflet, melakukan aksi di jalanan, dan menggalakan kegiatan anti korupsi di media sosial, dan menyoba memfasilitasi jika ada warga ada masalah dengan pemerintah, misalnya maslah pendidikan 9 tahun belajar gratis kok masih di punggut biaya dan kita beri tahu tetang undang-undang dasar, terkait UndangUndang Pendidikan, kita latih cara melakukan advokasi, bagaimana nanti cara menyampaikan dengan Dinas Pendidikan. Dan menyadarkan masyarakat bahwa mereka adalah pemantuan kebijakan pemerintah mereka juga bagian dari anti korupsi. Hal-hal tersebut di lakukan untuk memberikan pengetahuan anti korupsi dengan masyarakat dan mencegah para birokrat untuk melakukan korupsi dan untuk melakukan sebuah pelatihan advokasi ke warga agar mereka melek hukum juga (Wawancara dengan Kepala Sekretariat dan Dokumentasi).

Ada beberapa strategi yang dilakukan oleh MCW diantaranya: 1) Pencegahan. Korupsi terjadi karena adanya keinginan dari pelaku korupsi dan adanya rekan dinas atau jaringan dalam suatu instansi pemerintah yang terjadi secara masif dan sistematis dari hal itu maka pencegah hal- hal yang dijadikan strategi paling jitu untuk pemberantasaan korupsi. 2) Penegakan hukum. Penegakan hukum ini saya rasa kurang sebegitu berat untuk pelaku koruptor karena hukuman bagi koruptor tidak sebanding dengan yang mereka curi dari negara ini, dan jika mereka tertangkap dan terbukti tidak di miskinkan, seharusnya kusus untuk pelaku koruptor harus di miskinkan dan jika terbukti korupsi lebih dari 1.000.000.000 harus di hukum mati agar 
memberi efek jere bagi pelaku korupsi di negeri ini. 3) Edukasi dan kampanye anti korupsi, perlu di lakukan karena merupakan pembelajaran secara langsung untuk memberikan rasa takut kepada para koruptor dan pembelajaran secara langsung kepada masyrakat untuk tidak takut melaporkan kepada pihak berwajib jika terjadi penyelewengan dana. Hal ini di lakukan untuk pencegahan dan strategi jitu dan sebagai masukan juga untuk pemerintah untuk memberikan efek jera pada pelaku (Wawancara dengan Kepala Sekretariat dan Dokumentasi).

\section{Kinerja Malang Corruption Watch}

Ada beberapa dugaan kasus korupsi yang di lakukan oleh ER mantan Walikota Batu yaitu : 1) Kasus pertama yaitu penunggakan pajak hiburan dalam kurun waktu 2010-2014 penunggakan itu dilakukan oleh jatim park 1, 2, dan Batu Night Spectacular dengan total kerugian mencapai 24 M. 2) Dugaan kasus kedua, yaitu dugaan korupsi pengurangan piutang pajak hiburan Jatim Park 1 tahun 2012 dengan kerugian 2,2 M. 3) Dugaan kasus ketiga dugaan korupsi di PT. Batu Wisata kasus tersebut hanya menjerat sang direktur menyebabkan kerugian 1,2 M. 4) Dugaan kasus keempat yakni dugaan kasus korupsi Batu Roadshow tahun 2015 menyebabkan kerugiaan 1 M. 5) Dugaan kasus kelima yaitu dugaan korupsi pembangunan Block Office tahun 2009-2016. Total penganggaran mencapai 252 M. Namun tak ada kejelasan sampai saat ini. "ER" merupakan mantan walikota batu yang kini menjadi tahanan korupsi yang di lakukan oleh KPK selain itu lembaga Malang Corruption Watch juga membeberkan tentang kasus korupsi ER untuk di dalami KPK (Wawancara dengan Kepala Sekretariat dan Dokumentasi).

Keberadaan $M C W$ merupakan satu dari sekian banyak bukti yang menggagaskan bahwa masyarakat bisa dapat berperan proaktif dalam ranah kehidupan bernegara, negara membutuhkan suatu kontrol dari masyarakat dalam menjalankan perananya sebagai pelaksana kebijakan publik, karena masyarakat adalah objek yang vital. $M C W$ bisa dikatakan sebagai perwujudan dari kesadaran dan kepedulian seluruh masyarakat yang anti terhadap kejahaan korupsi. $M C W$ menjadi peran vital ketika berhasil membantu masyarakat dan pemerintah dalam memberantas korupsi. Kinerja $M C W$ harus benar benar mewakili hajat hidup orang banyak, dan tidak boleh terpengaruh oleh unsur politik yang datang darimana pun. Keberhasilan $M C W$ dalam mengungkap dan memonitor sebuah kasus, adalah bukti bahwa negara ini memerlukan pengawasan yang ekstra, apalagi untuk menangani kejahatan yang luar biasa (Extra Ordinary Crime) seperti korupsi. Di samping itu, pemerintah juga dapat mengevaluasi segala sektor yang agaknya perlu untuk dibenahi dengan cara menggandeng segala pihak untuk bekerjasama. Di samping itu, pemerintah selaku pemangku pemangku kebijakan juga harus melakukan inovasi maupun rekonstruksi hukum dan aturan yang dapat menurunkan tingkat kejahtan korupsi. Atau dengan kata lain, pemerintah harus 
Yusuf Adam Hilman, Herlambang Septa Nugraha

memaksimalkan kinerja aparatur negara dengan cara melakukan perekrutan dan pemupukan karakter aparatur negara yang harus dilakukan secara kesinambungan agar terbebas dari praktik korupsi. Keberadaan kasus korupsi yang tiada habisnya, apabila jika terus menerus terjadinya tentu dikhawatirkan melunturkan rasa kepuasaan dan kepercayaan masyarakat terhadap pemerintah. Pemerintah adalah pihak yang paling berpotensi dalam merumuskan segala arah dan solusi positif untuk membenahi aspek hukum yang mampu untuk memberikan ketegasaan dan keteraturan tentang Undang-Undang Tindak Pindana Korupsi. Pemerintah juga dapat menggandeng pihak-pihak independent seperti $M C W$ atau lembaga lain untuk terus mengontrol urusan kejahatan korupsi baik pusat atau daerah.

\section{KESIMPULAN}

Agenda-agenda yang dilakukan oleh Malang Corruption Watch adalah kegiatan monitoring korupsi di Malang Raya yang diarahkan menjadi gerakan moral dan gerakan sosial. Bahkan dikemudian hari gerakan-gerakan ini harus dilembagakan sebagai bagian dari proses demokratisasi sistem politik dan sistem ekonomi, sehingga nantinya diharapkan lembaga Malang Corruption Watch bisa mendorong terbentuknya sebuah perangkat nilai dan norma sosial yang adil, beradab dan berdaulat. Malang Corruption Watch yang digagas sebagai lembaga publik, maka siapapun boleh menjadi aktivis Malang Corruption Watch selama mempunyai kesamaan visi dan misi dalam agenda pemberantasan korupsi. Selain itu, Malang Corruption Watch adalah lembaga sosial yang independen nonpartisan dan terbuka yang memfokuskan pada pemantauan/pengawasan korupsi, advokasi dan pemberdayaan serta melakukan pendidikan publik. Dalam menjalankan agendanya support dana Malang Corruption Watch didapat dari donatur tetap internal (dewan pengurus, pembina, pengawas, badan pekerja) kini juga didapat dari penciptaan fund raising Malang Corruption Watch yang berbentuk penerbitan buku, sowvenir dan penjualan kaos serta didapat juga dari kerja sama dengan lembaga-lembaga pemberi dana dan penggalangan dana dari publik. Sebagai salah satu lembaga yang konsen dalam agenda pemberantasan korupsi, penguatan gerakan sosial anti korupsi merupakan asa yang harus dicapai.Agenda pemberantasan korupsi yang efektif, efisien dan independen merupakan harapan besar untuk mengeluarkan republik ini dari penyakit akut korupsi.Sehingga dukungan publik menjadi kunci untuk mendorong agenda pemberantasan korupsi yang kuat, agenda pemberantasan korupsi yang dapat mempercepat Indonesia keluar dari mata rantai kemiskinan dan kesejahteraan yang tertunda.Oleh karena itu, agenda pemberantasan korupsi terus dioptimalkan dan menguatkan lembaga antikorupsi yang telah ada di Indonesia.Untuk mencapai visi dan misi Malang Corruption Watch memerlukandukungan publik menjadi basis 
untuk menggalang kekuatan bersama dalam memerangi akut kosupsi di negeri ini.Sangat mustahil korupsi dapat dilumpuhkan apabila tatanan birokrasi, politik, ekonomi, pendidikan, dan hukum belum steril dan bebas dari korupsi, kolusi dan nepotisme. Seperti yang kita ketahui bahaya darikorupsi dapat merusak sendi-sendi moral kehidupan berbangsa dan bernegara. Oleh karena itu, gerakan sosial anti korupsi harus terus dikumandangkan untuk menciptakan iklim politik yang beretika, birokrasi bersih, ekonomi kerakyatan, pendidikan berkualitas dan hukum yang adil serta membangun generasi anti korupsi. Dalam mewujudkan hal tersebut, gendang perlawanan terus ditabuh untuk menyatakan perang melawan korupsi.

\section{DAFTAR PUSTAKA}

Acetylena, Sita. 2013. “Analisis Implementasi Kebijakan Pendidikan Karakter Di Perguruan Taman Siswa Kecamatan Turen Kabupaten Malang". Kebijakan dan Pengembangan Pendidikan 1(1):56-61.

Andrisman, Tri. 2008. Analisis Penegakan Hukum Tindak Pidana Korupsi Oleh Komisi Pemberantasan Korupsi (KPK).

Argenti, Gili. 2017. "Civil Society Dan Politik Moral Muhammadiyah". Politikom Indonesia Vol 2 (2): 82-104.

Azyumardi. 2002. "Korupsi Dalam Perspektif Good Governance”. Kriminologi. Vol. 2 (I):3136.

Damayanti, Ratnaningsih, Rachmad Gustomy, and Muhtar Haboddin. 2017. "Pendahuluan Perjalanan Yang Dilakukan Oleh Alexis de Tocqueville Di Amerika Pada Awal Abad Ke-19 Membuahkan Tulisan Democracy in America Yang Menjadi Rujuan Utama Bagi Studi Mengenai Masyarakat Sipil ( Civil Society ) Di Berbagai Negara . Kajian Tocquevil”. Ilmu Pemerintaban. Vol. 2 (April): 19-36.

Fawaid, Ahmad. 2010. "Islam, Budaya Korupsi Dan Good Governance.” KARSA Vol. XVII (1): $18-26$.

Hadi, Kisno. 2010. "Korupsi Birokrasi Pelayanan Publik Di Era Otonomi Daerah.” Jurnal Penelitian Politik. Vol. 7 (1):51-70.

Korupsi, Komisi Pemberatasan. 2018. Laporan Tahunan 2017 Demi Indonesia Untuk Indonesia.

Kurniawan, Teguh. 2009. "Peranan Akuntabilitas Publik Dan Partisipasi Masyarakat Dalam Pemberantasan Korupsi Di Pemerintahan." Ilmu Administrasi dan Organisasi Vol. 16 (2007): 5-10.

Larasati, Dinda. 2018. "Demokrasi Dan Organisasi Masyarakat Sipil: Malang Corruption Watch.” Sospol Vol. 4 (1): 168-84.

Muhsin, Ilyya. 2012. "Gerakan Penegakan Syariah: Studi Gerakan Sosial Hizbut Tahrir Indonesia Di DIY." Ijtihad Jurnal Wacana Hukum Islam dan Kemanusiaan Vol. 12 (2): 4361.

Nugroho, Bangun Setiyawan. 2014. "Pola Pendidikan Informal Dalam Organisasi Mahasiswa." Pendidikan Humaniora Vol. 2 (1): 89-101.

Nurlindah, Kaharudin, Suardi. 2016. "Gerakan Sosial Coremap Dalam Pelestarian Terumbu Karang.” Equilibrium, Jurnal Sosiologi, Pendidikan Vol. III (2): 185-94. 
Yusuf Adam Hilman, Herlambang Septa Nugraha

Pratomo, Dhinar Aji and Rachmat Kriyantono. 2013. "The Power of Media Effect: Construction Television as Media for Anti-Corruption Education in Indonesia." KKU International Journal of Humanities and Social Sciences Vol. 6(1): 1-9.

Salahudin, Vissanu Zumitzavan. 2016. "International Conference on Ethics In Governance Interesting Law Religion and Politics." Pp. 39-51 in A relationship Betwen Local Government and Civic Group in Budget Planning In Malang City.

Setyawan, Dody, Ignatius Adiwidjaja. 2014. "Strategi Meningkatkan Kesadaran Politik Dan Menolak Money Politic Pemilih Pemula Pada Pilkada Kota Malang." Reformasi Vol. 3 (2): 90-95.

Sina, La. 2008. "Dampak Dan Upaya Pemberantasan Serta Pengawasan Korupsi Di Indonesia." Hukum Pro Justitia Vol. 26 (1): 39-51.

Situmorang, Mosgan. 2014. "Harmonisasi Hukum Nasional Di Bidang Korupsi Dengan United Nations Convention Against Corruption.” Rechtsvinding Vol. 3 (3): 329-46.

Yuanjaya, Pandhu. 2015. "Modal Sosial Dalam Gerakan Lingkungan: Studi Kasus Di Kampung Gambiran Dan Gondolayu Lor, Kota Yogyakarta." Natapraja, Kajian Ilmu Administrasi Negara Vol. 3(1): 57-72.

CNN Indonesia, 2016. "KPK Jerat 63 Kepala Daerah dalam 1 Dekade”, diakses 15 Mei 2018 (https://www.cnnindonesia.com/nasional/20160928131449-12-161770/kpk-jerat-63kepala-daerah-dalam-1-dekade).

Inisiatif Masyarakat untuk Pendidikan Antikorupsi diakses pada pada 16 mei 2018 dari http://kpk.go.id/id/berita/berita-kpk-kegiatan/3981-inisiatif-masyarakat-untukpendidikan-antikorupsi. 